\title{
欧米で実施されている薬剤而性菌モニタリングシステムの現状
}

\author{
大倉正稔 $1 \cdot$ 佐藤真澄 ${ }^{2 *} \cdot$ 能田 健 $^{3}$ \\ 1 (独) 農研機構動物衛生研究所 細菌・寄生虫研究領域 \\ 2 (独) 農研機構動物衛生研究所 動物疾病対策センター \\ 3 農林水産省消費・安全局 畜水産安全管理課
}

\section{Overview of National Antimicrobial Resistance Monitoring System in Europe and the United States}

\author{
Masatoshi OKURA ${ }^{1}$, Masumi $\mathrm{SATO}^{2 *}$ and Ken $\mathrm{NODA}^{3}$ \\ ${ }^{1}$ Bacterial and Parasitic Disease Research Division, National Institute of Animal Health \\ ${ }^{2}$ Center for Animal Disease Control and Prevention, National Institute of Animal Health \\ ${ }^{3}$ Animal Products Safety Division, Food Safety and Consumer Affairs Bureau, \\ Ministry of Agriculture, Forestry and Fisheries
}

\begin{abstract}
Summary
National Antimicrobial Resistance Monitoring ; NARMS, USA), Danish Integrated Antimicrobial Resistance Monitoring and Research Programme ; DANMAP, Denmark) and Swedish Veterinary Antimicrobial Resistance Monitoring ; SVARM, Sweden) were investigated.

NARMS is a collaboration among the U. S. Food and Drug Administration (FDA), the U. S. Center for Disease Control and Prevention (CDC), U. S. Department of Agriculture (USDA). It monitors retail meat, human and food-producing animals. DANMAP is also an integrated system involving animals, retail meat and humans. Same as the National Veterinary Antimicrobial Resistance Monitoring System in Japan (JVARM), all systems monitor Salmonella spp., Campylobacter spp., Escherichia coli and Enterococcus spp.. In these systems, different from JVARM, they collect the animal samples in the slaughterhouse. In European countries, they emphasize to monitor the consumption of antimicrobials for food animals. In order to construct the better monitoring system, they often review the methods by themselves.
\end{abstract}

\section{はじめに}

薬剤耐性菌の出現はヒトの医療現場のみならず獣医学領 域に打いても重大な問題となっている。一方, 動物由来, ヒト由来，環境由来細菌は直接あるいは間接的に多様な経 路で相関しているため, 動物やヒトにおける薬剂耐性菌の 問題はそれぞれに関連した特定領域だけではなく，その問 題解決には「ヒト」,「動物」及び「環境」の全てを考慮す

\section{連絡先 : 佐藤真澄*}

(独) 農研機構動物衛生研究所 動物疾病対策センター 干305-0856 茨城県つくば市観音台 3-1-5

Tel : 029-838-7804; Fax : 029-838-7804

E-mail : masumi@affrc.go.jp
る必要がある。食品は, ヒトと動物（食用）間の細菌の伝 達経路の一つである。食肉供給のための食用動物において も，治療や成長促進のため抗菌性物質が使用されている。 世界保健機関（WHO）は，ヒトの医療に抢ける薬剂耐性 菌問題と食用動物への抗菌性物質使用との間の因果関係が 否定できないことから, 食用動物における抗菌性物質の禁 止や制限について提言している1)。しかし，両者の因果関 係の有無を明らかにするためには, 食品媒介性細菌の薬剤 耐性に関する科学的なモニタリング情報が必要であり, 国 際獣疫事務局 (OIE) は, 家畜衛生及び公衆衛生上問題と なる薬剂耐性菌を制御するための戦略の一つとして, 国際 的に比較可能な薬剤耐性モニタリングの重要性を指摘して いる的。 
我が国では，家畜衛生分野における抗菌性物質耐性菌の 調査体制として Japanese Veterinary Antimicrobial Resistance Monitoring System (JVARM) が 1999 年度より実施されて いる ${ }^{3)}$ 。JVARM では, (1)食用動物由来細菌における薬剂 耐性の発現状況をモニタリングすること(2)動物用抗菌剂の 有効性を確認すること(3)動物用抗菌剂等の使用量をモニ夕 リングすること(4)薬剤耐性菌に関するリスク分析の基礎資 料を提供すること(5)モニタリングで得られた成績を動物用 抗菌剂等の “慎重使用”に反映させることを目的に, 農林 水産省動物医薬品検査所をリファレンスラボとして, 全国 都道府県の家畜保健衛生所（約 170 力所）とのネットワー クが構築されており, 動物用抗菌剂等の使用実態調查及び 農場レベルでの耐性菌動向の把握・解析を主眼においた調 査が行われている。今回, 我々は今後の我が国の耐性菌モ ニタリングシステムの改善に資するために米国, デンマー ク及びスウェーデンの担当機関を訪問し各国における耐性 菌モニタリングシステムの現状について, 聞き取り調査を 行った。本稿ではサンプリングや調査方法を中心にその概 要を報告する。

\section{1. 米国の薬剤耐性菌モニタリングシステム}

\section{1-1. 概要}

米国が行っている薬剤耐性菌モニタリングシステム (National Antimicrobial Resistance Monitoring System ; NARMS) ではヒト, 精肉, 動物由来の食品媒介細菌における抗菌剂 耐性の動向を監視すること, 抗菌剂耐性に関する情報を夕 イムリーに発信し, 抗菌剤耐性の減少を促すこと, 抗菌剂 耐性の出現・持続・拡大について理解を深めるための研究 を行うこと, 安全かつ効果的な動物用抗菌薬承認に関連す るFDAの決定に役立てることを目的としている4)。米国 疾病予防管理センター (Centers for Disease Control and Prevention; CDC) がヒト, 食品医薬品局獣医学センター (Center for Veterinary Medicine, Food and Drug Administration, $\mathrm{FDA} / \mathrm{CVM}$ ) が精肉, 農業研究局細菌疫学 ・薬剤耐性菌工 ニット (Bacterial Epidemiology and Antimicrobial Resistance Research Unit, Agricultural Research Service ; ARS/BEAR) が 家畜の調査におけるリファレンスラボとしてそれぞれ機能 している。本システムでは保健社会福祉省の機関 (CDC, FDA）と農務省の機関（BEAR）の省庁を超えた連携がな されている。

抗菌剂の消費量については販売ベースのデータは把握し ているが, 本システム内には含まれていない。

\section{1-2. 調査菌種および方法，体制について}

\section{$1-2-1$. 家畜}

調査対象菌種は, Salmonella spp., Escherichia coli, Enterococcus spp., Campylobactor spp. である。
サンプリングは別の事業を通じて，連邦政府の検閲済み のと畜場及び処理プラントで行われ，と体洗浄液（鶏肉）, と体拭い液 (七面鳥, 牛, 豚), 挽肉サンプル (七面鳥, 鶏, 牛)を使用している。分離菌数は各菌種 500-2000株である。

菌の分離, 同定は, 全国 3 ヶ所の Food Safety and Inspection Service (FSIS) Regulatory Field Services Laboratory ま たはBEARで行われ，薬剤感受性試験は一括して BEAR で実施されている。

1-2-2. 精肉

調査対象菌種は, Salmonella spp., E. coli, Enterococcus spp., Campylobactor spp. である。Salmonella と Campylobacter に ついては 11 州で, E. coli と Enterococcus spp.については 現在 3 州で採材されている。サンプルは鶏胸肉, 七面鳥挽 肉, 牛挽肉, 豚骨付き肉で, スーパーマーケットや小売店 を毎月 10 店舗ランダムに選択し，採材している。毎年 5000 検体以上のサンプルが集まり，各菌種 1000-5000 株 ずつ分離されている。菌の分離までは州の公衆衛生ラボで 行われているが, 同定, 血清型別及び薬剂感受性試験は FDA/CVM で一括して行われている。

\section{1-2-3. ヒト}

調査対象菌種は, Salmonella spp. (Non-typhoidal, Typhi, Paratyphi A, Paratyphi B, Paratyphi C), E. coli O157, Shigella spp., Campylobactor spp. であり, 2010 年以降は E. coli, Enterococcus spp., Vibrio spp. についても調査が開始されてい る。別のサーベイランス事業と組み合わせることで, サン プリングの効率化を図っている。おおよその分離株数を設 定し (500-2000 株), 菌種によっては全分離株を使用せず, 全分離株の $1 / 10$ を使用する等, 調查に使用する分離株を 選択している。

菌の分離, 同定および血清型別までは州の公衆衛生研究 所で行われ，薬殽感受性試験は CDCで一括して行われて いる。

\section{1-3. 今後の動向}

家畜については，農場での採材やと畜場の立ち入り採材 が必要かについて検討しており, これらの施設内での採材 を試験的に開始している。また, 公衆衛生上問題となる, メチシリン耐性黄色ブドウ球菌（MRSA）やClostridium difficile 等の菌種の追加, ヒト, 食品, 家畜間での菌株レ ベルでの識別を行うシステムの拡充（パルスフィールド電 気泳動パターンを利用) やデータベースの一元化などの改 善を継続している。

\section{2. デンマークの薬剤耐性菌 モニタリングシステム}

\section{2-1. 概要}

デンマークが行っている薬剤耐性菌モニタリングシステ 
ム (Danish Integrated Antimicrobial Resistance Monitoring and Research Programme ; DANMAP) は，食用動物及びヒトに おける抗菌剂の消費量を監視すること, 食用動物・動物由 来食品・ヒトから分離される細菌の抗菌剤耐性を監視する こと, 抗菌剂消費と耐性の間の関連性について研究するこ と, 耐性伝達経路やさらなる調査研究が必要な地域を同定 することを目的としており，統合的で世界的にも最も洗練 されたシステムである ${ }^{5)}$ 。薬剤の使用量については, Danish Medical Association（DMA）及び Danish Register of Veterinary Medicines（VetStat）がそれぞれヒト用及び動物用に ついて，消費を監視する法的義務があり，月毎に処方及び 売上データを集約している。また，デンマークでは，全農 場及び全獣医師が ID コードで識別されており，抗菌剂の 使用についてもそれぞれ報告することが法律で義務づけら れている。耐性菌の動向監視のための調査については, 動 物及び精肉は National Food Institute (NFI) が, ヒトは Statens Serum Institut（SSI）がリファレンスラボとして機能して いる。米国同様, DANMAP においても厚生省と農水省が 連携してシステムを運営している。

\section{2-2. 調査菌種および方法, 体制について}

2-2-1. 家畜

調査対象菌種は, Salmonella spp. ( $S$. Typhimurium と $S$. Enteritidisのみ), E. coli, Enterococcus spp. (E. faecium と E. faecalis のみ), Campylobacter spp. (C. coli と C. jejuni のみ) 及び病畜由来大腸菌 [血清型 O149; 豚のみ, 血清型 F5 (K99)；牛のみ］である。院内感染で問題となっており, 食用動物も保有する菌種 [C. difficile, メチシリン耐性黄 色ブドウ球菌 (MRSA), バンコマイシン耐性腸球菌 (VRE), 基質特異性拡張型 $\beta$ ラクタマーゼ (ESBL) 産生大腸菌（多 剂耐性）などにについても個別に調査している。

Salmonella spp. についてはサルモネラサーベイランスシ ステムにより, 畜舎とと畜場の糞便（豚及び肉養䳕）から, E. coli, Enterococcus spp., Campylobacter spp.についてはと 畜場・食鳥処理場で, 豚（盲腸便，毎月）, 牛（直腸便, 毎月), 肉用鷄（クロアカスワブ, 毎週）の採材を行って いる。対象となる 17 ケ所のと畜場では全国で処理される 頭数の 9 割以上が処理されている。1 農場からは各菌種 1 分離株のみをモニタリング用のサンプルとしている。菌の 分離, 同定, 血清型別, および薬剤感受性試験は NFI で 一括して行われている。

2-2-2. 精肉

調査対象菌種は, Salmonella spp. ( $S$. Typhimurium と $S$. Enteritidisのみ), E. coli, Enterococcus spp. (E. faecium と E. faecalis のみ), Campylobactor spp. (C. coli と C. jejuni のみ) である。Salmonella spp.についてはサルモネラサーベイラ ンスプログラムを通じてと畜場の冷蔵熟成後の枝肉スワブ
(国産豚と国産牛のみ) 及び輸入肉（鵎肉, 七面鳥肉, 豚肉, 牛肉) から採材, E. coli, Enterococcus spp. (E. faecium と E. faecalis のみ), Campylobacter spp. については, 卸売り店 と小売店で収集した牛, 豚及び鵎肉検体 (Campylobacter spp. は鷂肉のみ）から採材している。国産肉と輸入肉の両 者について調査を行っており, 各肉サンプルにつき各菌種 1 分離株のみを使用している。菌の分離, 同定, 血清型別, および薬剤感受性試験はNFIで一括して行われている。

\section{2-2-3. ヒト}

調査対象菌種は, Salmonella spp. ( $S$. Typhimurium と $S$. Enteritidisのみ), E. coli, Enterococcus spp. (E. faecium とE. faecalis のみ), C. jejuni, MRSA, A, B, C, G 群レンサ球菌, Klebsiella pneumoniae, Pseudomonas aeruginosa である。基 本的には Departments of Clinical Microbiology（DCM）や病 院等で分離・同定された株がSSIに送付される。薬剤感受 性試験は Salmonella, C. jejuni, MRSA, A, B, C, G 群レンサ球 菌はSSIで一括して行われており，その他については DCM で行われている。

\section{2-3. 抗菌剤使用監視システム}

獣医診療及び農場における動物用抗菌剂の使用を評価・ 監視するため，これまでの DANMAP のデータをもとに， 豚に対する慎重使用についての新たなガイドラインを作成 している。本ガイドラインでは各薬剤について以下の 4 項 目について分析し，その值を基準に全農場及び全獣医師の ID を含む処方データにより抗菌剤使用について評価を 行っている。

1）効能（効能についての臨床的な証拠/文献）

2）感受性（National Food Institute と National Veterinary Instituteに送付された株間での感受性率)

3）薬剤動態（MIC kill/MIC50 に基づくスコア；MIC50は デンマーク国内のデータより，MICkill は MIC50 内の $80 \%$ を含む MIC 值)

4）ヒトの健康に基づくリスク結果（FDA 及び OIE のガ イドラインに従う)

2010 年 10 月から開始されたシステムでは, 抗菌剤消費 量の多い養豚農場（5-10\%）での使用が基準を超えた場合， 消費を抑えるよう警告し，一定期間中の再処方を禁止した り, 専門家の助言を受けさせたり, 強制的に抜き打ち調査 を行ったりしている。これらにかかる検査料や相談料は農 場経営者が負担する。

\section{2-4. 今後の動向}

上記の監視システム導入により, 2013 年度までに抗菌 剂使用 $10 \%$ 減（2009 年より）を目標にしている。また, 貿易の拡大や渡航者数の増加に伴い, 新たな耐性菌の出現 や耐性率の増加が確認されており, それに対応できるシス テム等新たなツールの開発も必要と考えている。 


\section{3. スウェーデンの薬剤耐性菌 モニタリングシステム}

\section{3-1. 概要}

スウェーデンが行っている薬剤耐性菌モニタリングシス テム (Swedish Veterinary Antimicrobial Resistance Monitoring ; SVARM）は, 介入の必要性がある耐性の動向を検出する こと, 臨床現場での適切な薬剤の選択の推奨となる基礎 データを提供することを目的に行っている

対象は動物及び食肉に限定しており，ヒトについては別 のモニタリングシステム (Antibiotic Consumption and Resistance in Sweden ; SWEDRES) があり，1 冊にまとめた年 次の報告を発行しているが, 両者が連携している訳ではな い。使用量については，獣医師による処方データの報告は 義務づけられておらず, 売上データのみから動物種を推定 している。使用量に関しては Swedish Board of Agriculture （SBA）が法的監視を行っている。

耐性菌の動向調査については, National Veterinary Institute (SVA) がリファレンスラボとして機能している。し かし, 予算や人員等の関係から, 毎年動物種を限定した調 査を行っており, 食用動物については, 1 年毎に鵎, 豚, 牛と, 動物種を絞って, 順番に実施している。また, 対象 は食用動物だけでなく，年により菌種や動物種を変えなが ら馬や犬, 猫, 野生動物, 魚介類と幅広く耐性菌の調査を 行っている。

\section{3-2. 調査菌種および方法, 体制について}

調査対象菌種は, Salmonella spp., E. coli, Enterococcus spp. (E. faecium と E. faecalis のみ), Campylobactor spp., MRSA, 及び動物病原体である。Salmonella spp.については国内に おける哺乳動物の届出伝染病として SVAに送付された各 分離株を材料としている。また, 国内のサルモネラの調査 事業でと畜場から収集した検体（食肉スワブ, 頸部の皮膚, リンパ節）からの分離株も包括して行っており，これらの 分離・同定はSVA または地方の公衆衛生研究所で行い, 血清型別はSVA で行っている。Campylobactor spp., E. coli, Enterococcus spp. はと畜場サンプルから分離している。肉 用鶏は国内全体の $99 \%$ 以上を処理している 7 ヶ所の食肉 処理場で盲腸内容物 200 検体 (2 月-5 月, 9 月-11月に各 100 検体ずつ） から採材している。豚は国内全体の $90 \%$ 以上を処理している 9 ヶ所のと畜場で, 結腸内容物 (3 月5 月，9月-11月に各 100 検体程度）からランダムに採材 している。牛に関しては, 年により対象を子牛, 乳牛と変 えている。2008 年は 6-8 ケ月齢の子牛を対象として国内 全体の $92 \%$ を処理していると畜場で, 結腸内容物（3 月, 4 月，8月，9月-11月に各群 1 頭選択）から 200-300 検体, ランダムに採材した。いずれの畜種の採材数も各処理場の
年次のと畜数に比例しており，それぞれ産地が同じことも あるが，異なる群由来のものを用いている。Salmonella spp. を除く, 菌の分離, 同定については, ほとんどが SVA で実施され，薬剤感受性試験も SVA が一括して行ってい る。

\section{3-3. 今後の動向}

政府主導ではないため, データを利用したリスク評価や リスク管理を行うには至っていない。調査したデータから 耐性菌の問題や動向についての情報を積極的に獣医や農家 に提供し，自発的に慎重使用するように促すという形での 実施を継続している。

\section{4. まとめ}

今回の調査の結果，米国とデンマークでは，省庁を越え たプロジェクトにより家畜・食肉・ヒトに関する統合的な モニタリングシステムが機能していることがわかった。調 査菌種はいずれの国も Salmonella spp., Campylobacter spp., E. coli, Enterococcus spp. で，これはわが国の JVARM と同 様であった。いずれの国も家畜由来材料の採取は基本的に と畜場で行われていたが，米国においては，これらを農場 で採材する必要があるかどうかの検討を 2010 年から試験 的に始めていた。欧州では抗菌郕使用量の把握を重点的に 行っており，欧州全体での動向調査を目指している(2009 年までに 9 力国が参画)。また，米国においては，モニ夕 リング手法について毎年検討し，頻繁に見直しを行ってい た。

\section{5. 謝辞}

本調査は, 平成 22-24 年度レギュラトリーサイエンス新 技術開発事業の成果であり，遂行にあたり，ご協力頂いた 運営チーム（農林水産省 消費・安全局 畜水産安全管理 課）の皆様に感謝致します。

また，本調査にあたり，情報提供のみならず，貴重なご 意見，ご助言を賜りました各国の調査機関 [米国 (CDC, FDA/CVM, BEAR), デンマーク (NFI, SSI) 及びスウェー デン（SVA）］の研究者及びスタッフの皆様に深甚なる感 謝の意を表します。

\section{参考文献}

1) Terakado, N. et al. : Jpn.J. Vet. Sci., 42, 543-550, 1980

2) OIE Guidelines on Antimicrobial Resistance, 2002

3) A Report on the Japanese Veterinary Antimicrobial Resistance Monitoring System -2000 to 2007- National Veterinary Assay Laboratory Ministry of Agriculture, Forestry and Fisheries, Tokyo, 2009

4) NARMS 2010 Executive Report. The Food and Drug Ad- 
ministration's Center for Veterinary Medicine (CVM), 2012

5) DANMAP 2010. Staens Serum Institut, Danish Medicines Agency, National Veterinary Institute, National Food
Institute, 2011

6) SVARM 2010. National Veterinary Institute, 2011 